\title{
Aanbesteden van sociale diensten: nieuwe spelregels
}

Niels Uenk, Jan Telgen, Tim Robbe

Overheidsopdrachten boven een bepaalde drempelwaarde moeten Europees worden aanbesteed. Voor onder andere sociale dienstverlening (diensten in het kader van de Wmo 2015, Jeugdwet, Participatiewet en Passend Onderwijs) mochten gemeenten tot 18 april 2016 op basis van de Europese en Nederlandse aanbestedingswetgeving een bijzondere procedure voeren (procedure voor 2B diensten). Binnen de overkoepelende beginselen van het aanbestedingsrecht hadden gemeenten grote vrijheid om naar eigen inzicht deze inkoopprocedure vorm te geven. Per 18 april 2016 zijn bepalingen uit de nieuwe Europese richtlijn van kracht. Het regime voor sociale diensten is daarmee veranderd.

In dit artikel beschrijven wij kort de achtergrond van de oude wet- en regelgeving. We behandelen daarna de nieuwe richtlijn en consequenties daarvan voor de inkooppraktijk in het sociaal domein. Tot slot pleiten we voor een landelijk richtsnoer rondom inkoopprocedures in het sociaal domein, om zo gemeenten duidelijkheid te verschaffen - en de grote diversiteit die op zorgaanbieders dreigt af te komen binnen de perken te houden.

\section{Achtergrond aanbestedingsrecht en 'oude regime' voor sociale diensten}

Centrale en decentrale overheden moeten zich voor het plaatsen van overheidsopdrachten houden aan Europese en nationale regels. Kort samengevat heeft wetgeving gebaseerd op deze regels tot doel om een gezamenlijke Europese markt te creëren, waarbij alle ondernemers uit EU-lidstaten gelijke kansen krijgen om overheidsopdrachten uit te voeren binnen de hele Europese Unie. Overheden moeten hiertoe opdrachten vanaf een bepaalde waarde centraal publiceren en via een aanbestedingsprocedure gunnen aan de geschikte ondernemer die de beste offerte aanbiedt. Bij een aanbestedingsprocedure moet de overheid altijd transparant, proportioneel en non-discriminatoir handelen en alle deelnemende ondernemers gelijk behandelen.

Sommige overheidsopdrachten zijn echter zo specifiek een lokale aangelegenheid dat de Europese wetgever niet van lidstaten verlangt dat ze voor ondernemers uit de hele EU worden opengesteld. Het zijn opdrachten waarbij een zogenaamde "duidelijk grensoverschrijdend belang" ontbreekt: de Europese wetgever gaat er vanuit dat deze opdrachten doorgaans niet interessant zijn voor ondernemers uit andere lidstaten. De oude Europese richtlijn voor overheidsopdrachten (2004/18/EU) bevatte een lijst met diensten - op bijlage 2A - waarop de hele richtlijn van toepassing was: bijvoorbeeld schoonmaakdiensten, ICT-dienstverlening en vervoersdiensten. Tevens bevatte de oude richtlijn een lijst diensten - op bijlage $2 \mathrm{~B}$ - die uitgezonderd waren van de concrete bepalingen uit de richtlijn, bijvoorbeeld ten aanzien van publicatieplicht, procedures, en termijnen. Sociale zorg en ondersteuning vielen in de oude richtlijn onder 'sociale diensten' en waren opgenomen op bijlage 2B. Aanbestedende diensten waren bij het inkopen van dergelijke diensten verplicht zich te houden aan de algemene beginselen van aanbestedingsrecht (transparantie, gelijkheid, non-discriminatie, proportionaliteit) en regels voor het stellen van technische specificaties, maar mochten verder geheel zelf bepalen hoe ze een inkoopprocedure voor dergelijke diensten inrichtten. Enkel publicatie achteraf van de gunningsbeslissing was verplicht. Deze verplichting om gunning te publiceren heeft 
de Europese wetgever overigens ingevoerd om opdrachtverlening van dergelijke $2 \mathrm{~B}$ diensten wel te kunnen volgen, om in een later stadium mogelijk de werking van de richtlijn ook op $2 \mathrm{~B}$ diensten toe te passen.

De Europese richtlijn 2004/18/EU is in Nederland omgezet in de Nederlandse Aanbestedingswet 2012, waarbij Nederland ten aanzien van het onderscheid tussen $2 \mathrm{~A}$ en 2B-diensten en het beperkte regime voor $2 \mathrm{~B}$ diensten niet van de Europese richtlijn is afgeweken. De vrijheid van het $2 \mathrm{~B}$-regime heeft in Nederland bijgedragen aan een grote verscheidenheid in inkoopprocedures voor diensten in het sociaal domein.

\section{Nieuwe Richtlijn 2014/24/EU}

De Europese wetgever heeft bij het introduceren van de (oude) richtlijn 2004/18/EU al duidelijk gemaakt dat ook de '2B-diensten' ooit mogelijk onder de volledige werking van aanbestedingsregels komen te vallen. In de nieuwe richtlijn is het onderscheid tussen 2A- en 2B-diensten afgeschaft. Dit betekent dat op alle diensten de hele aanbestedingsrichtlijn van kracht is geworden. Echter, voor een aantal 'bijzondere' diensten, waaronder sociale diensten is een aparte set regels opgesteld. Voor die diensten introduceert de richtlijn een nieuw drempelbedrag van $€ 750.000$. Opdrachten voor sociale diensten met waarde boven deze drempel moeten ook vooraf openbaar gepubliceerd worden, zoals dat bij andere diensten al moet bij een drempelbedrag van $€$ 209.000. De Europese richtlijn verplicht de lidstaat vervolgens om voor die sociale diensten een te volgen inkoopprocedure vast te stellen, maar laat het verder aan de lidstaten zelf om invulling te geven aan die procedure. De Nederlandse regering kiest er op dit moment voor om zelf geen nadere procedure uit te werken in de nieuwe Nederlandse aanbestedingswet. Zij stelt dat de oude procedure voor de 2B diensten nog steeds van toepassing is. Op het eerste oog lijkt er dus niet veel te veranderen: enkel de toevoeging van het publiceren vooraf.

\section{Consequentie nieuwe richtlijn voor inkoop in het sociaal domein}

Nederland is te laat met het implementeren van de Europese richtlijn in de Nederlandse aanbestedingswet: dit had op 18 april moeten gebeuren. $\mathrm{Er}$ is nu gekozen om de conceptwet die in de Tweede Kamer is behandeld - en die naar verwachting medio 2016 door de eerste kamer zal worden aangenomen - met 'terugwerkende kracht' vanaf 18 april 2016 geldig te verklaren voor de inkoop van 'bijzondere diensten' zoals in het sociaal domein.

Dit betekent dat vanaf 18 april een gemeente opdrachten in het sociaal domein met een totale contractwaarde boven de $€ 750.000$ openbaar moet publiceren op het daartoe bij wet aangewezen platform (TenderNed). Omdat de waarde van de opdracht gedurende de looptijd van het contract in zijn geheel moet worden berekend, zal zelfs een kleine zelfstandig inkopende gemeente diensten onder de Wmo 2015, Jeugdwet en Participatiewet moeten publiceren. Hoewel de richtlijn geen verdere procedurele verplichtingen stelt, gaat er door de publicatieplicht vooraf impliciet een aantal verplichtingen gelden. $\mathrm{Na}$ de aankondiging, waarin de gemeenten duidelijk moeten maken hoe zij de procedure gaan insteken, hoe zij gaan gunnen en hoe zij ondernemers daarvoor uitnodigen, moeten alle ondernemers de mogelijkheid krijgen hun interesse kenbaar te maken. Gemeenten moeten vervolgens de procedure en gunning zoals gemotiveerd uitvoeren.

Zelfs onder experts op het gebied van aanbestedingsrecht en inkoop in het sociaal domein is er discussie over de mogelijkheden om de huidige inkooppraktijken voort te zetten onder de nieuwe 
richtlijn. Hieronder geven wij een opsomming van nieuwe plichten. Ter volledigheid geven we ook een overzicht van praktijken die ook onder de nieuwe richtlijn nog steeds mogelijk zijn.

Nieuwe plichten, en wat mag na 18 april 2016 niet meer:

- gemeenten moeten opdrachten in het sociaal domein boven de $€ 750.000$ op Tenderned publiceren

Hierdoor is niet langer toegestaan:

- opdrachten boven deze drempel één-op-één uit de hand te gunnen

- alleen huidige zorgaanbieders uitnodigen voor een inkoopprocedure

- $\quad$ een opdracht wezenlijk te wijzigen zonder opnieuw de opdracht te publiceren

De publicatieplicht heeft dus consequenties voor enkele praktijken die in 2014 bij de inkoop van de Wmo en jeugdzorg nog door veel gemeenten werden toegepast.

Wat naar onze mening nog steeds kan:

- in een marktconsultatie (marktdialoog) met zorgaanbieders informatie ophalen over de vormgeving van de opdracht (zowel voorafgaand, tijdens als na de inkoopprocedure), zolang alle partijen gelijk worden behandeld en de marktconsultatie niet leidt tot een kennisvoorsprong bij bepaalde partijen. Om een kennisvoorsprong te vermijden bij een marktconsultatie kan de gemeente bijvoorbeeld de resultaten van de marktconsulatie openbaar publiceren.

- een raamovereenkomst met meerdere partijen afsluiten die geen omzetgarantie biedt, maar waarin standaard voorwaarden en standaard-tarieven voor dienstverlening vastliggen. De individuele cliënt zelf kiest zijn zorgaanbieder naar keuze, en geeft daarbij invulling aan EMVI / BPKV ${ }^{1}$ (gunningscriterium kwaliteit)

\section{Gevolgen inkooppraktijk}

De Nederlandse wetgever heeft bij de implementatie van de Europese richtlijn ervoor gekozen géén nadere procedure voor sociale diensten uit te werken. Daardoor ontstaat nu onduidelijkheid over de plichten: in hoeverre worden andere procedurele aspecten verplicht nu een gemeente de opdracht vooraf moet aankondigen?

Maar wellicht nog belangrijker zijn de gevolgen voor de aanbieders. Doordat er geen procedurele aspecten worden voorgeschreven, kunnen gemeenten allerlei procedures bedenken binnen de basis principes van het Europees aanbestedingsrecht. Dat betekent dat iedere gemeente voor ieder in te kopen product (begeleiding, huishoudelijke hulp, dagbesteding, alle jeugdzorgproducten, etc.) een andere procedure mag hanteren. En dat veelal ook zullen doen, zoals is gebleken bij de recente aanbestedingen. Je zult maar als aanbieder met tientallen zo niet honderden verschillende procedures met verschillende eisen geconfronteerd worden! Ook nu al zijn er signalen dat de administratieve lasten bij de aanbieders enorm zijn toegenomen als gevolg van de verschillende procedures en contractvoorwaarden waarmee de aanbieders te maken hebben.

\footnotetext{
${ }^{1}$ In een aanbesteding op basis van Economisch Meest Voordelige Inschrijving of Beste Prijs-Kwaliteit Verhouding worden prijs en kwaliteitsaspecten afgewogen om de beste leverancier(s) te selecteren, in tegenstelling tot aanbestedingen op laagste prijs, waarbij alleen de aangeboden prijs doorslaggevend is.
} 
Zeker is dat zowel de Nederlandse als Europese wetgever niet beogen om onduidelijkheid en administratieve lasten te vergroten: noch in de Wmo, noch in de Jeugdwet, noch in de Participatiewet, noch in de Europese Richtlijn, noch in de Aanbestedingswet 2016.

De wetgever had er in onze ogen goed aan gedaan om juist wél een duidelijke richting of duidelijk richtsnoer mee te geven bij de implementatie van de nieuwe Nederlandse aanbestedingswet. Juist om extra administratieve lasten te voorkomen en het geld te kunnen besteden aan de zorg zelf, is een meer sturende uitwerking van de verplichting van de lidstaat om een procedure voor het inkopen van sociale diensten vast te stellen, zinvol. 